\title{
Myoclonus Associated with Celiac Disease Responsive to Anti-Epileptics and a Gluten-Free Diet
}

\author{
Youstina Hanna ${ }^{a, b}$ Parul Tandon ${ }^{\text {b, } c}$ Zane Gallinger ${ }^{b, c}$ \\ aDepartment of General Internal Medicine, University of Toronto, Toronto, ON, Canada; \\ ${ }^{\mathrm{b}}$ Faculty of Medicine, University of Toronto, Toronto, ON, Canada; 'Division of \\ Gastroenterology and Hepatology, Mount Sinai Hospital, Toronto, ON, Canada
}

\section{Keywords}

Celiac disease $\cdot$ Myoclonus $\cdot$ Gluten-free diet $\cdot$ Anti-epileptics

\begin{abstract}
We report on the case of a 61-year-old male who initially presented with a progressive myoclonus and an intention tremor and was subsequently diagnosed with celiac disease. His neurological symptoms improved with anti-epileptic therapy and a gluten-free diet. Possible explanations include a milder disease phenotype or an epileptic component to his myoclonic movement disorder. This case highlights findings of a progressive myoclonic movement disorder, likely linked to celiac disease, and stresses the importance of a gluten-free diet in the management of the neurological manifestations of celiac disease.
\end{abstract}

(C) 2021 The Author(s)

Published by S. Karger AG, Basel

\section{Introduction}

Celiac disease, or gluten-sensitive enteropathy, is an autoimmune condition characterized by gastrointestinal symptoms of diarrhea, abdominal pain, and weight loss. A diagnosis often requires confirmation of serum anti-tissue transglutaminase (TTG) antibody formation and

\begin{tabular}{ll}
\hline & Zane Gallinger \\
Karger & Mount Sinai Hospital, University of Toronto \\
& 600 University Ave \\
& Toronto ON M5G 1X5 (Canada) \\
& Zane.Gallinger@sinaihealthsystem.ca
\end{tabular}




\section{Case Reports in Gastroenterology}

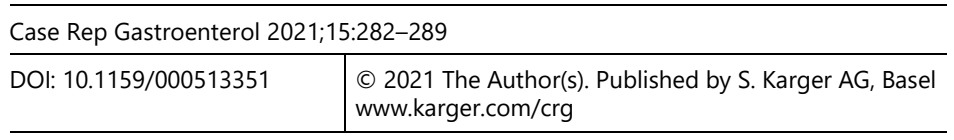

Hanna et al.: Myoclonus Associated with Celiac Disease Responsive to Anti-Epileptics and a Gluten-Free Diet

histologic abnormalities of the small bowel [1]. In genetically susceptible individuals, exposure to gliadin results in the breakdown of inter-enterocyte tight junctions, cell-lysis, and an increase in intestinal permeability. As a result, gliadin enters the lamina propria and is deaminated by TTG resulting in an immunogenic compound that is presented on the antigen-presenting cells, through HLA-DQ2 and HLA-DQ8. Ultimately, this results in cytokine production, enterocyte damage, and antibody development to TTG [1].

The clinical spectrum of celiac disease is diverse, with numerous extraintestinal manifestations such as anemia, osteoporosis, arthralgias, and neurological manifestations [2]. The most common neurological associations previously reported are ataxia, peripheral neuropathy, and epilepsy, which tend to improve with a gluten-free diet (GFD) [3, 4]. Myoclonus is less commonly recognized, has been associated with refractory celiac disease, and generally fails to improve with anti-epileptic drugs (AED) or a GFD [5]. Here, we report a unique case of myoclonus in a patient with non-refractory celiac disease which improved with AED and GFD therapy.

\section{Case Presentation}

A 61-year-old Caucasian male initially presented to the emergency department with a 1month history of a progressive left arm action-induced myoclonus and an intention tremor. His past medical history was remarkable for a right hip arthroplasty for osteoarthritis, hypertension, asthma, a 45-pack-year smoking history, and alcohol use disorder (average of 8 beers [112-144 $\mathrm{g}$ of alcohol] per day for 40 years), though he stopped drinking 4 days prior to hospital presentation. His medications on presentation included perindopril and inhaled fluticasone.

On history, he reported new and involuntary movements of his left arm which were jerky, occurring only with action, and interfering with his occupation, professional dog walking. These movements spared his lower extremities, but he reported some difficulty with balance. He denied any other neurological symptoms to suggest coordination or sensory abnormalities, cognitive impairments, or psychiatric changes. On further history, he also reported a chronic history of loose bowels and difficulty gaining weight. There was no significant family history for any gastrointestinal, neurological, or movement disorders.

On examination, he was a thin-appearing male, weighing $56 \mathrm{~kg}$. His cardiovascular, respiratory, and abdominal exams were normal. His neurological exam was remarkable for a left arm large-amplitude intention tremor and an action-induced myoclonus that disappeared at rest. Myoclonic jerk-like movements of his proximal left arm, involving the pectoralis and trapezius muscles, were also noted. The remainder of the neurological examination was normal, including cranial nerves, power, tone, sensory, coordination, reflex examination, and gait. He did not have any ataxia or bradykinesia on exam.

He was briefly admitted to hospital and initially seen by the inpatient neurology service. A comprehensive workup revealed a normal complete blood count, electrolytes, extended electrolytes, vitamin $B_{12}$, copper, vitamin $E$, and ceruloplasmin levels. Serum thyroid-stimulating hormone and alkaline phosphatase were also normal, whereas the aspartate

\section{Karger'=}




\section{Case Reports in Gastroenterology}

Case Rep Gastroenterol 2021;15:282-289

DOI: $10.1159 / 00051335$

(C) 2021 The Author(s). Published by S. Karger AG, Basel www.karger.com/crg

Hanna et al:: Myoclonus Associated with Celiac Disease Responsive to Anti-Epileptics and a Gluten-Free Diet

aminotransferase and alanine transaminase were mildly elevated at $66 \mathrm{U} / \mathrm{L}$ (7-40) and 60 U/L (10-45), respectively. Serum celiac profile revealed a positive serum TTG-IgA of 170 $\mathrm{U} / \mathrm{mL}(<15 \mathrm{U} / \mathrm{mL})$ with a normal serum IgA of $4.6 \mathrm{~g} / \mathrm{L}$.

Brain magnetic resonance imaging (MRI) with gadolinium enhancement revealed no significant abnormalities. Electroencephalography was normal, despite capturing abnormal movements. A diffuse weighted imaging MRI of the spine revealed non-specific degenerative changes. An abdominal computed tomography revealed a thickened and mildly distended small bowel (shown in Fig. 1d) with jejunization of the ileum (shown in Fig. 1a) and numerous low attenuation lymph nodes of the small bowel mesentery and porta hepatus (shown in Fig. 1c) with evidence of splenic atrophy (shown in Fig. 1b).

He was discharged shortly after, without any medications, and was seen in an outpatient neurology clinic 1 month after initial presentation for further evaluation. At that time, he continued to have persistent, though stable, symptoms. He was prescribed a trial of low-dose clonazepam, which resulted in minimal improvement in his symptoms with significant sedative side effects. He represented to the emergency department and was reassessed by the neurology service, who prescribed valproic acid $250 \mathrm{mg}$ twice daily. Within a couple of days, he had a marked improvement of his symptoms, with a significant decrease in the frequency of arm movements.

He was subsequently referred to outpatient gastroenterology for management of presumed celiac disease. An EGD performed 4 months after initial presentation revealed an edematous duodenum. Biopsies showed flattened villi consistent with celiac disease (shown in Fig. 2). He was prescribed a GFD with the assistance of a trained registered dietician. Celiac serology repeated a month after his initial appointment revealed a TTG-IgA of $28 \mathrm{U} / \mathrm{mL}$ with improvement in gastrointestinal symptoms.

Unfortunately, he suffered a relapse of his alcohol use disorder and had a beer bingedrinking episode followed by self-discontinuation of valproic acid. This resulted in significant worsening of his movements, which progressed to involve his bilateral lower extremities, impairing his ability to ambulate. He suffered a fall requiring re-admission to hospital. During this stay, valproic acid, at the previously prescribed dose, was resumed with immediate and significant improvement in symptoms. Due to a mild elevation in liver enzymes, however, he was subsequently switched to levetiracetam $1 \mathrm{~g}$ twice daily, with sustained improvement in myoclonus. On discharge, he was able to ambulate independently.

His symptoms relapsed a third time when he self-discontinued the levetiracetam for 2 days, due to significant side effects of dizziness. He was admitted to hospital and had two complex partial seizures off anti-epileptics. He was restarted on levetiracetam $1 \mathrm{~g}$ twice daily as well as valproic acid $250 \mathrm{mg}$ twice daily with, once again, drastic improvement in symptoms and the ability to use his affected left arm and ambulate independently.

After 3 months on a strict GFD, remission of his alcohol use disorder, and adherence to anti-epileptics, he was seen in follow-up. Despite an initial drastic improvement shortly after initiating anti-epileptics, his symptoms had progressed, though they were still remarkably better than his symptoms off anti-epileptics. His gastrointestinal symptoms had resolved with an undetectable TTG-IgA. His myoclonus remained stable 7 months after that visit and he continues to follow up at the neurology clinic for uptitration of anti-epileptics as needed. 


\section{Case Reports in Gastroenterology}

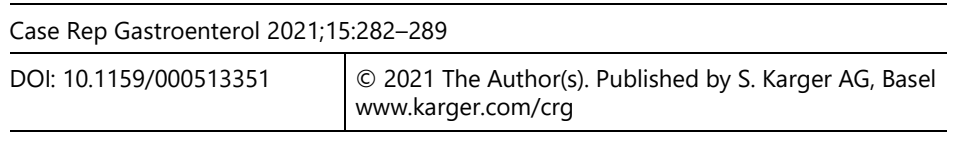

Hanna et al.: Myoclonus Associated with Celiac Disease Responsive to Anti-Epileptics and a Gluten-Free Diet

\section{Discussion}

We report on a 61-year-old male who initially presented with an action-induced myoclonus and was subsequently diagnosed with celiac disease. Celiac-associated myoclonus has been previously described. Case reports have identified patterns of a progressive myoclonus unresponsive to a GFD or AED [6] (Table 1). This is in contrast to other neurological manifestations of celiac disease, which can often be well managed with AED and strict adherence to a GFD [3].

We present a rather unusual phenotype of celiac-associated myoclonus, with minimal ataxia, with a response to AED and a GFD. Worsening of his movement disorder with the ingestion of significant amounts of gluten-containing alcohol, and improvement in the setting of a GFD and a declining serum anti-TTG supports the therapeutic role of a GFD. Additionally, our patient demonstrated, on three separate occasions, a significant and immediate improvement in myoclonus in response to AEDs. Despite lack of complete resolution, AEDs improved our patient's myoclonus significantly and prevented progression, allowing him to ambulate and remain independent in his activities of daily living.

There are several reasons that could explain our patient's unique response. Irreversible neurological manifestations of celiac disease are usually associated with imaging findings of cerebellar atrophy on MRI [7]. Antibody-mediated destruction of Purkinje cells and perivascular inflammation have been previously described to account for these findings. Gluten toxicity and malabsorption-associated vitamin E deficiency have also been suggested [3]. The lack of imaging findings in our patient suggests the absence of Purkinje cell destruction, which could be associated with a milder disease phenotype or earlier recognition, and in turn management, of the disease process. Additionally, while previous reports of myoclonus have been associated with refractory celiac disease, our patient's abdominal symptoms and serologic markers resolved on a GFD (specifically, in the absence of gluten-containing alcohol) suggesting a non-refractory disease process and resolution of immune-mediated destruction [5]. A partial response in neurological symptoms to a GFD highlights the importance of a dietician consult and strict adherence to GFD. Finally, his response to AEDs, unlike previously described, as well as the occurrence of seizures, suggests a possible epileptic component to his movement disorder. Epilepsy associated with celiac disease is a well-described entity that is responsive to AEDs and a GFD [4].

This case highlights a potentially reversible myoclonic movement disorder associated with celiac disease, responsive to AEDs and a GFD. Patients presenting with celiac diseaseassociated neurologic disease should be managed by a multidisciplinary health care team including gastroenterologists, neurologists, physiotherapists, and social workers.

\section{Statement of Ethics}

This project was conducted with full compliance of internationally accepted ethical standards for research practice and reporting. Written informed consent was obtained from the patient for the publication of the case details.

\section{Karger'=}




\section{Case Reports in Gastroenterology}

\section{Conflict of Interest Statement}

None of the authors have any conflicts of interest or disclaimers.

\section{Funding Sources}

No funding was obtained.

\section{Author Contributions}

Dr. Gallinger was the most responsible physician and conceptualized the case report. He supervised and contributed to the case report interpretation, and he assisted and approved the final manuscript as submitted. Dr. Tandon contributed substantially to the case report interpretation and manuscript review. He has approved the final manuscript as submitted. Dr. Hanna contributed substantially to the case report interpretation and drafted the manuscript. She has approved the manuscript as submitted.

\section{References}

1 Parzanese I, Qehajaj D, Patrinicola F, Aralica M, Chiriva-Internati M, Stifter S, et al. Celiac disease: from pathophysiology to treatment. World J Gastrointest Pathophysiol. 2017 May;8(2):27-38.

2 Losurdo G, Principi M, Iannone A, Amoruso A, Ierardi E, Di Leo A, et al. Extra-intestinal manifestations of non-celiac gluten sensitivity: an expanding paradigm. World J Gastroenterol. 2018 Apr;24(14):1521-30.

3 Mearns ES, Taylor A, Thomas Craig KJ, Puglielli S, Leffler DA, Sanders DS, et al. Neurological manifestations of neuropathy and ataxia in celiac disease: A systematic review. Nutrients. 2019 Feb;11(2):E380.

4 Morris JS, Ajdukiewicz AB, Read AE. Neurological disorders and adult coeliac disease. Gut. 1970 Jul;11(7):549-54.

5 Sarrigiannis PG, Hoggard N, Aeschlimann D, Sanders DS, Grünewald RA, Unwin ZC, et al. Myoclonus ataxia and refractory coeliac disease. Cerebellum Ataxias. 2014 Sep;1(1):11.

6 Bhatia KP, Brown P, Gregory R, et al. Progressive myoclonic ataxia associated with coeliac disease. The myoclonus is of cortical origin, but the pathology is in the cerebellum. Brain. 1995 0ct;118(Pt 5):1087-93.

7 Javed S, Safdar A, Forster A, Selvan A, Chadwick D, Nicholson A, et al. Refractory coeliac disease associated with late onset epilepsy, ataxia, tremor and progressive myoclonus with giant cortical evoked potentials - a case report and review of literature. Seizure. 2012 Jul;21(6):482-5.

8 Paramanandam V, Hadjivassiliou M, Olszewska DA, Munteanu T, Williams L, Magennis B, et al. Reversible Corticobasal Syndrome due to Coeliac Disease. Mov Disord Clin Pract (Hoboken). 2018 Oct;5(5):551-4.

9 Khwaja GA, Bohra V, Duggal A, Ghuge VV, Chaudhary N. Gluten sensitivity - A potentially reversible cause of progressive cerebellar ataxia and myoclonus - A case report. J Clin Diagn Res. 2015 Nov;9(11):0D07-08.

10 Sallem FS, Castro LM, Jorge C, Marchiori P, Barbosa E. Gluten sensitivity presenting as myoclonic epilepsy with cerebellar syndrome. Mov Disord. 2009 Oct;24(14):2162-3.

11 Fung VS, Duggins A, Morris JG, Lorentz IT. Progressive myoclonic ataxia associated with celiac disease presenting as unilateral cortical tremor and dystonia. Mov Disord. 2000 Jul;15(4):732-4.

12 Smith GD, Saldanha G, Britton TC, Brown P. Neurological manifestations of coeliac disease. J Neurol Neurosurg Psychiatry. 1997 Oct;63(4):550-1.

13 Tison F, Arne P, Henry P. Myoclonus and adult coeliac disease. J Neurol. 1989 Jul;236(5):307-8.

14 Lu CS, Thompson PD, Quinn NP, Parkes JD, Marsden CD. Ramsay Hunt syndrome and coeliac disease: a new association? Mov Disord. 1986;1(3):209-19. 


\section{Case Reports in Gastroenterology}

Case Rep Gastroenterol 2021;15:282-289

(C) 2021 The Author(s). Published by S. Karger AG, Basel www.karger.com/crg

Hanna et al.: Myoclonus Associated with Celiac Disease Responsive to Anti-Epileptics and a Gluten-Free Diet
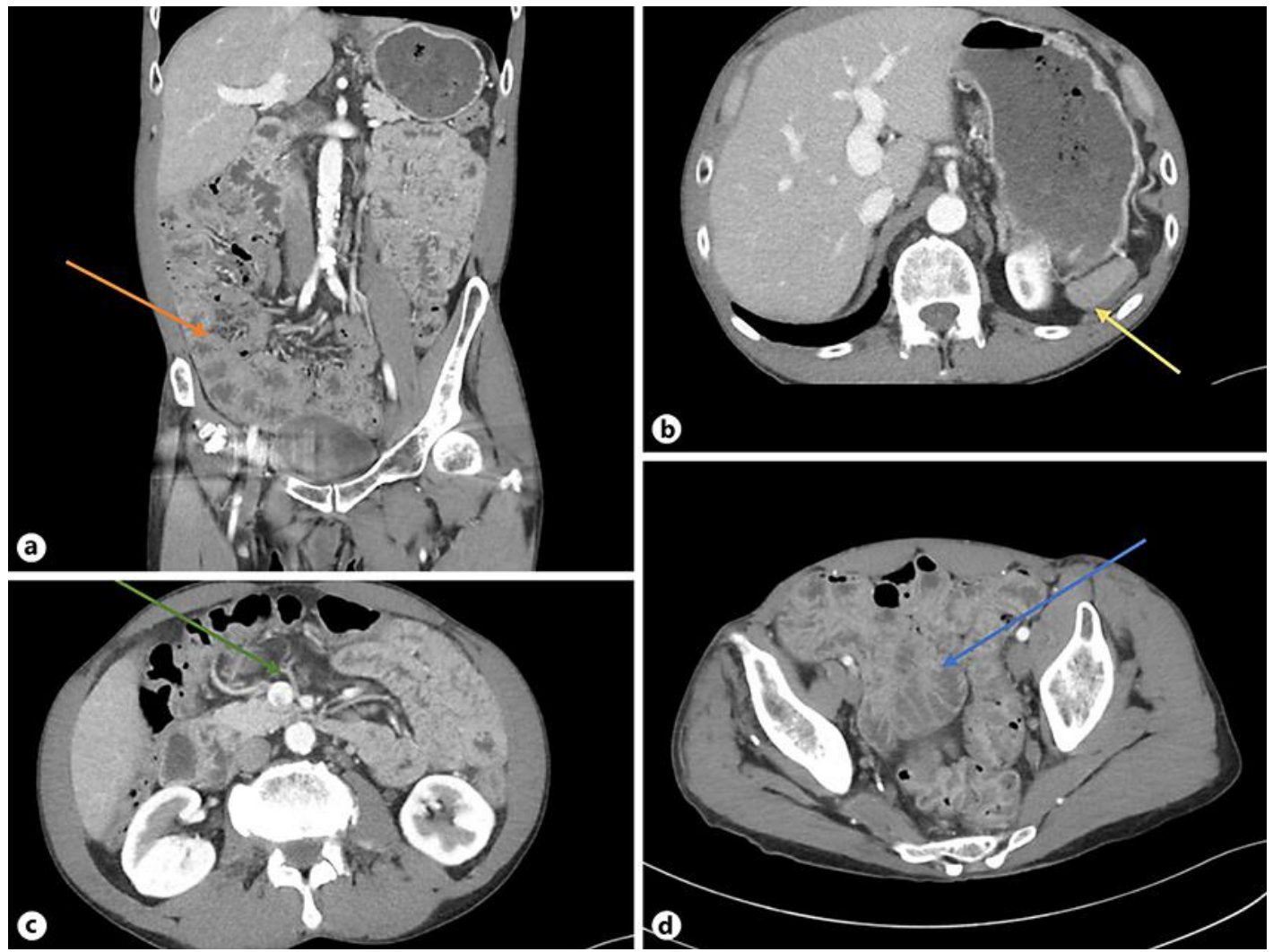

Fig. 1. a Abdominal CT, coronal view depicting jejunization of the ileum (orange arrow). b Abdominal CT, axial view depicting splenic atrophy (yellow arrow). c Abdominal CT, axial view depicting hypoattenuating nodes (green arrow). d Abdominal CT, axial view depicting distended small bowel (blue arrow). 
Case Reports in

\section{Gastroenterology}

Case Rep Gastroenterol 2021;15:282-289

(c) 2021 The Author(s). Published by S. Karger AG, Basel www.karger.com/crg

Hanna et al:: Myoclonus Associated with Celiac Disease Responsive to Anti-Epileptics and a Gluten-Free Diet

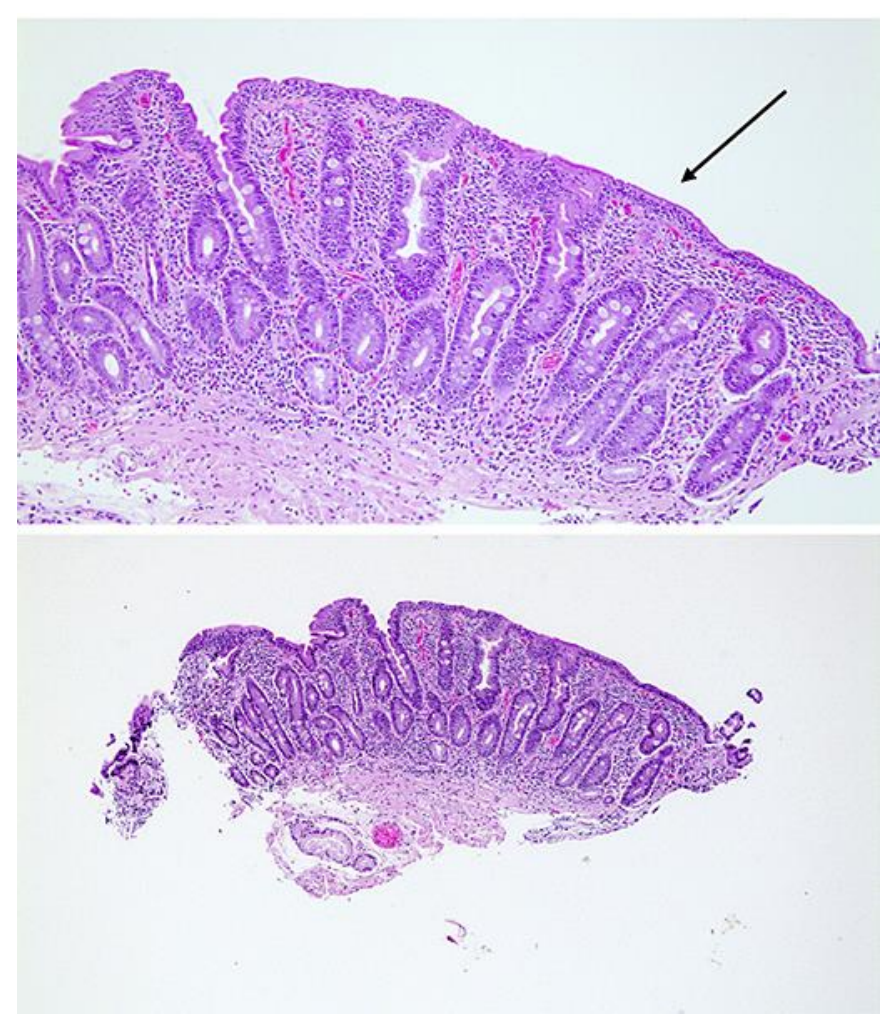

Fig. 2. Histology of small bowel biopsy. Flattened villi depicted by the black arrow in the top image (400x magnification). The image below is displayed at $50 \times$ magnification. 


\section{Case Reports in Gastroenterology}

\begin{tabular}{l|l}
\hline Case Rep Gastroenterol 2021;15:282-289 \\
\hline DOI: 10.1159/000513351 & $\begin{array}{l}\text { ( ) 2021 The Author(s). Published by S. Karger AG, Basel } \\
\text { www.karger.com/crg }\end{array}$ \\
\hline
\end{tabular}

Hanna et al.: Myoclonus Associated with Celiac Disease Responsive to Anti-Epileptics and a Gluten-Free Diet

Table 1. Review of the literature surrounding celiac disease and myoclonus

\begin{tabular}{|c|c|c|c|c|c|}
\hline Authors & $\begin{array}{l}\text { Sample } \\
\text { size }\end{array}$ & $\begin{array}{l}\text { Refractory } \\
\text { celiac disease } \\
(\mathrm{Y} / \mathrm{N}) ?\end{array}$ & Neurological manifestations & MRI findings & Outcome \\
\hline $\begin{array}{l}\text { Paramanandam } \\
\text { (2018) [8] }\end{array}$ & 1 & Y & $\begin{array}{l}\text { Ataxia, myoclonus, tremor, partial } \\
\text { seizures }\end{array}$ & Mild cerebellar atrophy & $\begin{array}{l}\text { Seizures responded to levetiracetam } \\
\text { but patient remained wheelchair bound }\end{array}$ \\
\hline $\begin{array}{l}\text { Khwaja (2015) } \\
\text { [9] }\end{array}$ & 1 & $\mathrm{~N}$ & $\begin{array}{l}\text { Slurred speech, hand clumsiness, } \\
\text { gait unsteadiness }\end{array}$ & Pan-cerebellar atrophy & Gait ataxia resolved with GFD \\
\hline $\begin{array}{l}\text { Sarrigiannis } \\
(2014)[5]\end{array}$ & 9 & $\mathrm{Y}$ & Myoclonus & Mild cerebellar atrophy & $\begin{array}{l}\text { Epilepsy controlled with AED; myoclo- } \\
\text { nus remained despite maximum doses } \\
\text { of AED/mycophenolate/rituximab }\end{array}$ \\
\hline $\begin{array}{l}\text { Javed (2012) } \\
\text { [7] }\end{array}$ & 1 & $\mathrm{~N}$ & $\begin{array}{l}\text { Myoclonus, tremor, ataxia and } \\
\text { complex seizures }\end{array}$ & Bilateral cerebellar atrophy & $\begin{array}{l}\text { No improvement with levetiracetam } \\
\text { and GFD }\end{array}$ \\
\hline $\begin{array}{l}\text { Sallem (2009) } \\
{[10]}\end{array}$ & 1 & Y & $\begin{array}{l}\text { Seizures, lower extremity myoclo- } \\
\text { nus, cerebellar syndrome }\end{array}$ & Normal & $\begin{array}{l}\text { No improvement with sodium } \\
\text { valproate, clonazepam, primidone, to- } \\
\text { piramate, or with GFD }\end{array}$ \\
\hline $\begin{array}{l}\text { Fung (2000) } \\
{[11]}\end{array}$ & 1 & $\mathrm{~N} / \mathrm{A}$ & $\begin{array}{l}\text { Tremor, limb myoclonus, tonic- } \\
\text { clonic seizures, gait ataxia }\end{array}$ & $\begin{array}{l}\text { Periventricular hyperinten- } \\
\text { sities }\end{array}$ & $\begin{array}{l}\text { No improvement with clonazepam or } \\
\text { carbamazepine }\end{array}$ \\
\hline $\begin{array}{l}\text { Smith (1997) } \\
\text { [12] }\end{array}$ & 1 & $\mathrm{~N}$ & Myoclonus, ataxia & $\mathrm{N} / \mathrm{A}$ & Slow progression \\
\hline $\begin{array}{l}\text { Bhatia (1995) } \\
\text { [6] }\end{array}$ & 4 & $\mathrm{~N}$ & Myoclonic, ataxic syndrome & $\begin{array}{l}\text { Symmetrical cerebellar atro- } \\
\text { phy, multiple tiny high-sig- } \\
\text { nal areas in bilateral white } \\
\text { matter }\end{array}$ & $\begin{array}{l}\text { Some improvement with clonazepam } \\
\text { and sodium valproate, no benefit with } \\
\text { lamotrigine }\end{array}$ \\
\hline $\begin{array}{l}\text { Tison (1989) } \\
\text { [13] }\end{array}$ & 1 & $\mathrm{~N}$ & Myoclonus & $\begin{array}{l}\text { Bilateral hyperintense white } \\
\text { matter lesions }\end{array}$ & $\begin{array}{l}80 \% \text { improvement with clonazepam, } \\
\text { piracetam, and vitamin E }\end{array}$ \\
\hline $\begin{array}{l}\mathrm{Lu}(1986) \\
{[14]}\end{array}$ & 2 & $\mathrm{~N}$ & $\begin{array}{l}\text { Myoclonus, epilepsy, cerebellar } \\
\text { ataxia }\end{array}$ & $\mathrm{N} / \mathrm{A}$ & $\begin{array}{l}\text { GFD, clonazepam, and carbamazepine } \\
\text { improved seizure but not ataxia and } \\
\text { myoclonus }\end{array}$ \\
\hline
\end{tabular}

